\title{
Spectrophotometric Determination of Iron(II) after Solid Phase Extraction of Its 2,2' Bipyridine Complex on Silica Gel-Polyethylene Glycol
}

\author{
Nahid Pourreza, Saadat Rastegarzadeh, Ali Reza Kiasat, and Hossein Yahyavi \\ Chemistry Department, College of Science, Shahid Chamran University, Ahvaz, Iran \\ Correspondence should be addressed to Nahid Pourreza; npourreza@yahoo.com
}

Received 27 June 2012; Accepted 28 August 2012

Academic Editor: Annemarie Wagner

Copyright (C) 2013 Nahid Pourreza et al. This is an open access article distributed under the Creative Commons Attribution License, which permits unrestricted use, distribution, and reproduction in any medium, provided the original work is properly cited.

A new solid phase extraction procedure was developed for preconcentration of iron(II) using silica gel-polyethylene glycol (silicaPEG) as an adsorbent. The method is based on retention of iron(II) as $2,2^{\prime}$ bipyridine complex on silica-PEG. The retained complex is eluted by $1.0 \mathrm{~mol} \mathrm{~L}^{-1}$ of sulfuric acid-acetone mixture (1:2) and its absorbance is measured at $518 \mathrm{~nm}$, spectrophotometrically. The effects of different parameters such as $\mathrm{pH}$, concentration of the reagent, eluting reagent, sample volume, amount of adsorbent, and interfering ions were investigated. The calibration graph was linear in the range of $1-60 \mathrm{ng} \mathrm{mL}^{-1}$ of iron(II). The limit of detection based on $3 \mathrm{~S}_{\mathrm{b}}$ was $0.57 \mathrm{ng} \mathrm{mL}$ and relative standard deviations (R.S.D) for ten replicate measurements of 12 and $42 \mathrm{ng} \mathrm{mL}$ of iron(II) were 2.4 and $1.7 \%$, respectively. The method was applied to the determination of of iron(II) in water, multivitamin tablet, and spinach samples.

\section{Introduction}

Nowadays, the extraction and determination of trace metal ions from different matrices have become of great importance and have received more attention. Among heavy metals, iron in small amounts is an essential element for most life on Earth, including humans and animals. It is well known that an iron deficiency is the most common cause of anemia. On the other hand, too much iron can cause several health problems. High levels of iron are associated with an increased risk for cancer, heart, and liver diseases [1]. Therefore iron determination is of great interest and is crucial to develop simple, rapid, and efficient methods for monitoring iron in the environment.

Modern instrumental methods including ICP-MS, ICPAES, and AAS [2-8] have been used for the determination of traces of metal ions in various media. However, spectrophotometry and flame atomic absorption spectrometry (FAAS) are the most available instrumental techniques in laboratories but their sensitivity and selectivity are usually insufficient for direct determination of elements at a very low concentration levels in real samples. Therefore, a separation/preconcentration step prior to the analysis is usually necessary for complex matrix environmental samples [7].

Solid phase extraction (SPE) has been used as a great tool for the separation and preconcentration of metal ions in different samples [8].The important advantages of solid phase extraction such as flexibility, simplicity, being economical, high enrichment factors, low cost because of lower consumption and, being environment friendly have made SPE as an attractive technique for separation/preconcentration of heavy metal ions [9-11]. The choice of appropriate sorbent for solid phase extraction is a critical parameter in order to obtain full recovery and high enrichment factor [12]. For this reason introducing new sorbent is still a challenge for analytical chemists. Various sorption materials, such as functionalized silica or alumina [13, 14], carbon materials [15], naphthalene [16], and molecular-imprinted polymers (MIPs) [17] have been used for this purpose.

We have recently introduced silica gel-polyethylene glycol (silica-PEG) as an adsorbent for preconcentration of cobalt and nickel [18] followed by flame atomic absorption spectrometric determination. In this paper a different 
aspect for using this adsorbent is presented and a new solid phase extraction method for preconcentration of trace iron(II) prior to its determination by spectrophotometery is established. Iron(II) as $2,2^{\prime}$ bipyridine complex was passed through a column containing silica-PEG. The retained complex was then eluted by sulfuric acid-acetone mixture $(1: 2)$ and its absorbance was measured at $518 \mathrm{~nm}$ by a spectrophotometer.

\section{Experimental}

2.1. Instrumentation. A GBC model Cintra 101, UV-Visible spectrophotometer (Sidney, Australia) was used for recording absorption spectra and absorbance measurements using $1 \mathrm{~cm}$ glass cells. A digital pH-Meter model 632, Metrohm (Herisau, Switzerland), with a combined glass electrode, was used for $\mathrm{pH}$ adjustments. A Tebazma vacuum pump (Tehran, Iran) was used for pumping the solutions.

2.2. Reagents. Analytical reagent-grade chemicals were used. A stock solution of $1000 \mu \mathrm{g} \mathrm{mL}^{-1} \mathrm{Fe}(\mathrm{II})$ was prepared by dissolving $0.7020 \mathrm{~g}$ of $\left(\mathrm{NH}_{4}\right)_{2} \mathrm{Fe}\left(\mathrm{SO}_{4}\right)_{2} \cdot 6 \mathrm{H}_{2} \mathrm{O}$ (Merck, Darmstadt, Germany) in water and diluting to $100 \mathrm{~mL}$ in a volumetric flask. $6.4 \times 10^{-4} \mathrm{~mol} \mathrm{~L}^{-1}$ of $2,2^{\prime}$ bipyridine (Merck) was prepared by dissolving $0.01 \mathrm{~g}$ in water and diluting to $100 \mathrm{~mL}$ in a volumetric flask. A phosphate buffer $\mathrm{pH} 8$ was prepared by diluting $4.8 \mathrm{~mL}$ phosphoric acid (Merck) to $250 \mathrm{~mL}$ in a volumetric flask and then adjusting its $\mathrm{pH}$ to 8 by adding $1.0 \mathrm{~mol} \mathrm{~L}^{-1} \mathrm{NaOH}$ (Merck) and using a $\mathrm{pH}$ meter. Silica gel (Aldrich, USA, 70-270 mesh, $60 \AA$, surface area $>500 \mathrm{~m}^{2} / \mathrm{g}$ ) was activated by treatment with $5 \mathrm{mom} \mathrm{L}^{-1} \mathrm{HCl}$ (Merck) and dried in vacuum at $120^{\circ} \mathrm{C}$. PEG was heated at $80^{\circ} \mathrm{C}$ under vacuum for $30 \mathrm{~min}$ before use to remove traces of moisture.

2.3. Adsorbent Preparation by Immobilization of Polyethylene Glycol on Silica Gel. An oven dried $250 \mathrm{~mL}$ flask equipped with a magnetic stirrer was charged with dried activated silica gel $(20 \mathrm{~g})$ under nitrogen atmosphere. Then freshly distilled $\mathrm{SOCl}_{2}(45 \mathrm{~mL})$ was added slowly to the flask through an addition funnel and the reaction mixture was stirred at room temperature. Evolution of copious amounts of $\mathrm{HCl}$ and $\mathrm{SO}_{2}$ occurred instantaneously. After stirring for $4 \mathrm{~h}$, the excess unreacted thionyl chloride was distilled off and the resulting grayish silica chloride was flame dried and stored in airtight container before use.

To a well-stirred silica chloride $(20 \mathrm{~g})$ in dry $\mathrm{CH}_{2} \mathrm{Cl}_{2}$ $(40 \mathrm{~mL})$ PEG ( $10 \mathrm{~g})$ was added dropwise under nitrogen atmosphere and at room temperature. $\mathrm{HCl}$ was instantaneously evaluated. After stirring for $2 \mathrm{~h}$, the obtained silicagel-supported PEG was removed by filtration. For elimination of any additional PEG, the PTC was washed several times by acetone $(3-30 \mathrm{~mL})$. Silica-gel-supported PEG was dried in a vacuum oven overnight [19] and was used as an adsorbent in this work.

2.4. Recommended Procedure. $0.1 \mathrm{~g}$ of silica-PEG adsorbent was placed in a glass tube $(7 \mathrm{~cm}$ length and $7 \mathrm{~mm}$ i.d) with a very fine bore and used as a preconcentration column. $250 \mathrm{~mL}$ of the solution containing $1-60 \mathrm{ng} \mathrm{mL}^{-1}$ of iron(II), $2 \mathrm{~mL}$ of $6.4 \times 10^{-4} \mathrm{~mol} \mathrm{~L}^{-1} 2,2^{\prime}$ bipyridine, and $5 \mathrm{~mL}$ of phosphate buffer $\mathrm{pH} 8$ was passed through the mini column at a flow rate of $10 \mathrm{~mL} \mathrm{~min}{ }^{-1}$. The adsorbed iron complex was eluted with $2.0 \mathrm{~mL}$ of $1.0 \mathrm{~mol} \mathrm{~L}^{-1}$ of sulfuric acid-acetone mixture $(1: 2)$. The absorbance of the color complex was measured at $518 \mathrm{~nm}$. A blank solution was also run under the same analytical conditions without adding any $\mathrm{Fe}(\mathrm{II})$.

2.5. Sample Pretreatments. The tap water sample was collected, acidified, boiled, and filtered. An aliquot of water sample was then treated under recommended procedure.

Fresh spinach sample was purchased from local market Ahvaz, Iran. It was washed thoroughly with water and dried in an oven at $100^{\circ} \mathrm{C}$ for $7 \mathrm{~h}$. It was then grinded to produce a fine powder. $12 \mathrm{~g}$ of this powder was placed in a porcelain crucible and burned on a flame until there was no fume. It was then placed in a muffle furnace at $600^{\circ} \mathrm{C}$ for $5 \mathrm{~h} ; 2 \mathrm{~mL}$ of hydrochloric acid was added and boiled for $30 \mathrm{~min}$. It was then filtered and diluted to $50 \mathrm{~mL}$ in a volumetric flask. An aliquot of this solution was taken and treated under the recommended procedure.

The content of a multivitamin tablet was dissolved in water; $5 \mathrm{~mL}$ of hydrochloric acid $10 \%$ was added, filtered, and diluted to $250 \mathrm{~mL}$ in a volumetric flask. An aliquot of this solution was taken and treated under the recommended procedure.

\section{Results and Discussion}

The PEG-grafted silica particles are special type of branched inorganic-organic copolymer which has polyether functional groups in the side chains that have been found to be stable to acid, base, high temperature, and oxygen. Its FT-IR spectrum shows the presence of $\mathrm{OH}$ and ethylene oxide groups on the surface of the adsorbent. Our preliminary experiments showed that iron(II) as 2,2' bipyridine complex is retained by silica-PEG. The $2,2^{\prime}$ bipyridine complex is probably adsorbed through interaction with $\mathrm{OH}$ groups of the PEG. Since the amounts of the complex retained on the adsorbent is very small, the FT-IR spectrum after loading the complex shows very slight shifts.

The absorption spectra of eluted complex from the column by sulfuric acid-acetone mixture (Figure 1) showed that maximum absorption takes place at $518 \mathrm{~nm}$. Therefore absorbance measurements were conducted at this wavelength. In order to achieve the highest performance for the system, the effect of different parameters such as $\mathrm{pH}$, concentration of the reagent, type and concentration of eluent flow, rates and amount of adsorbent on the solid phase extraction were studied.

3.1. The Effect of $p H$. It has been mentioned in the literature that $\mathrm{Fe}(\mathrm{NN})$ chelates such as iron(II)-2,2' bipyridine complex are stable in the $\mathrm{pH}$ range of 3-10 [20]. Therefore, the influence of the $\mathrm{pH}$ of the sample solution on the iron(II) 


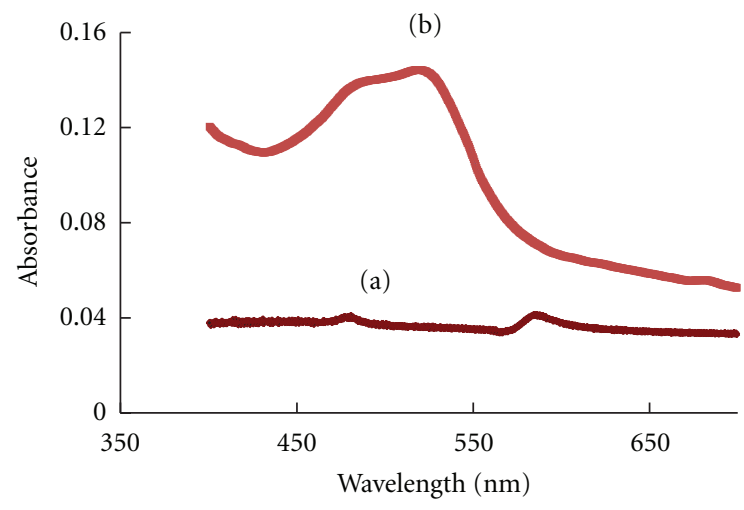

FIGURE 1: Absorption spectra of (a) blank and (b) the eluted iron(II) as $2,2^{\prime}$ bipyridine complex from the column.

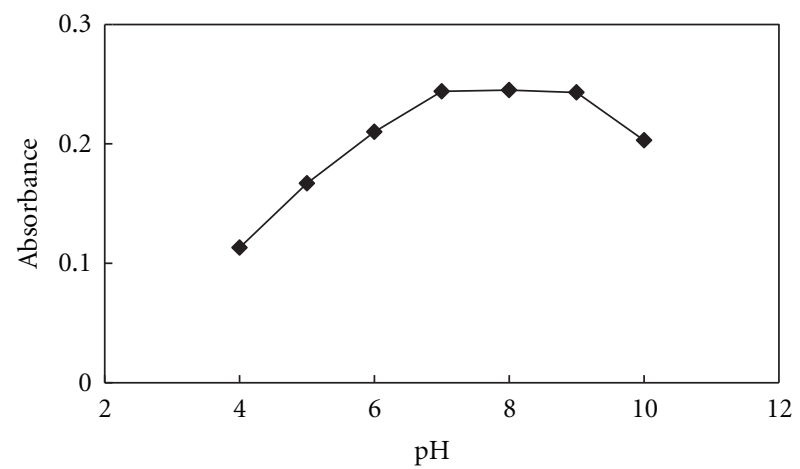

FIGURE 2: Effect of $\mathrm{pH}$ on the absorbance of $50 \mathrm{ng} \mathrm{mL}^{-1}$ iron(II) as $2,2^{\prime}$ bipyridine complex after desorption from the column.

ions as $2,2^{\prime}$ bipyridine complex formation and hence its adsorption on the silica-PEG adsorbent were studied. For this purpose, the $\mathrm{pH}$ value of a set of solutions $(100 \mathrm{~mL})$ each containing $50 \mathrm{ng} \mathrm{mL}^{-1}$ of iron(II) was adjusted in the range of $4.0-10.0$ by adding $0.1 \mathrm{~mol} \mathrm{~L}^{-1}$ of $\mathrm{HCl}$ or $\mathrm{NaOH}$. The obtained solutions were passed through the column, eluted by sulfuric acid-acetone mixture $(1: 2)$, and the absorbance of the color complex was measured at $518 \mathrm{~nm}$. According to the results shown in Figure 2, the absorbance is constant over the $\mathrm{pH}$ range of 7.0-9.0. Therefore, $\mathrm{pH} 8$ was selected as optimum for further work and $5 \mathrm{~mL}$ of phosphate buffer $\mathrm{pH}$ 8 was added to $100 \mathrm{~mL}$ solutions to maintain this $\mathrm{pH}$.

\subsection{Effect of the Ligand Concentration. The effect of $2,2^{\prime}$} bipyridine concentrations on the absorbance of iron(II)-2,2' bipyridine complex eluted from the column was investigated. The results indicated that the absorbance was increased up to a ligand concentration of $0.96 \times 10^{-5} \mathrm{~mol} \mathrm{~L}^{-1}$ and became almost constant above that (Figure 3). For this reason, the present study was carried out with a ligand final concentration of $1.28 \times 10^{-5} \mathrm{~mol} \mathrm{~L}^{-1}$ as optimum value. Thus $2.0 \mathrm{~mL}$ of $6.40 \times 10^{-4} \mathrm{~mol} \mathrm{~L}^{-1}$ of $2,2^{\prime}$ bipyridine was added to $100 \mathrm{~mL}$ solutions to maintain this concentration.

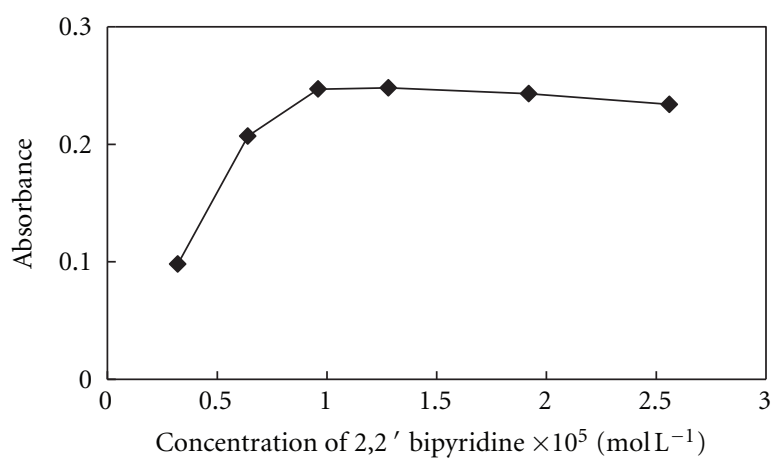

FIGURE 3: Effect of 2,2' bipyridine concentrations on the absorbance of $50 \mathrm{ng} \mathrm{mL}{ }^{-1}$ iron(II) as $2,2^{\prime}$ bipyridine complex after desorption from the column.

TABLE 1: Effect of different eluents on the absorbance of eluted $\mathrm{Fe}(\mathrm{II})-2,2^{\prime}$ bipyridine complex.

\begin{tabular}{lc}
\hline Eluent & Absorbance \\
\hline Acetone & 0.05 \\
DMSO & 0.04 \\
$\mathrm{H}_{2} \mathrm{SO}_{4}\left(1 \mathrm{~mol} \mathrm{~L}^{-1}\right)$ & 0.06 \\
$\mathrm{HCl}\left(1 \mathrm{~mol} \mathrm{~L}^{-1}\right)$ & 0.03 \\
$\mathrm{HNO}_{3}\left(1 \mathrm{~mol} \mathrm{~L}^{-1}\right)$ & 0.04 \\
Acetonitrile- $\mathrm{H}_{2} \mathrm{SO}_{4}\left(1 \mathrm{~mol} \mathrm{~L}^{-1}\right)$ & 0.27 \\
Acetone- $\mathrm{H}_{2} \mathrm{SO}_{4}\left(1 \mathrm{~mol} \mathrm{~L}^{-1}\right)$ & 0.78 \\
Acetonitril- $\mathrm{HCl}\left(1 \mathrm{~mol} \mathrm{~L}^{-1}\right)$ & 0.18 \\
\hline
\end{tabular}

3.3. Choice of Eluent. The other important factors which could affect the solid phase extraction procedure are the type, volume, and concentration of the eluent used for desorption of metal complex from the adsorbent. In order to choose a proper eluent for the retained complex after its extraction, the analyte was eluted with a series of selected eluents such as various inorganic acids, organic solvents, and their mixtures. The results of this investigation presented in Table 1 show that among different eluents used sulfuric acid-acetone mixture provided the highest absorbance for the eluted complex. Therefore, this solution was chosen as an eluent for further investigations. The sulfuric acid concentration and $\mathrm{H}_{2} \mathrm{SO}_{4}$ acetone ratio were also optimized. According to the obtained results $\mathrm{H}_{2} \mathrm{SO}_{4}$ concentration of $1.0 \mathrm{~mol} \mathrm{~L}^{-1}$ with a ratio of $1: 2\left(\mathrm{H}_{2} \mathrm{SO}_{4}\right.$-acetone $)$ was most suitable solvent for eluting the complex from the column. The effect of eluent volume was also investigated and $2 \mathrm{~mL}$ of $1: 2\left(\mathrm{H}_{2} \mathrm{SO}_{4}\right.$-acetone) was found to be adequate for the elution of retained iron(II)-2,2' bipyridine complex from the column.

3.4. The Effect of the Mass of Adsorbent. In order to test the effect of the mass of adsorbent on quantitative retention of iron(II)-2,2' bipyridine complex different amounts of silicaPEG adsorbent were chosen and the experimental method was applied. The results showed that quantitative adsorption for the complex was obtained in the range of 0.05- $0.25 \mathrm{~g}$ of adsorbent. Quantitative adsorption was not obtained when 
the mass of extractant was smaller than $0.05 \mathrm{~g}$. Thus $0.10 \mathrm{~g}$ of silica-PEG was selected for further studies.

3.5. The Effect of Flow Rate. In a solid phase extraction procedure, the flow rate of sample solution not only affects the recoveries of the analytes, but also controls the analysis time. Therefore, the effect of sample solution flow rate was examined under the optimum conditions by passing $100 \mathrm{~mL}$ of sample solution through the minicolumn at different flow rates. It was found that the retention of iron(II)$2,2^{\prime}$ bipyridine complex was independent of flow rate up to $10 \mathrm{~mL} \mathrm{~min}^{-1}$ and the absorbance of the solution was decreased slightly when the flow rate was over $10 \mathrm{~mL} \mathrm{~min}^{-1}$. Therefore, a flow rate of $10 \mathrm{~mL} \mathrm{~min}^{-1}$ was employed in this work.

3.6. The Effect of Breakthrough Volume. In order to achieve a high preconcentration factor, the breakthrough volume of sample solution should be established. The effect of sample volume on the adsorption of iron(II)-2,2' bipyridine complex was studied in the range of $100-500 \mathrm{~mL}$. Each solution contained same amount of $\mathrm{Fe}^{2+}(5 \mu \mathrm{g})$ and the adsorption and desorption processes were performed under the optimum conditions. The results showed that the Fe$2,2^{\prime}$ bipyridine present in various volumes of solution was completely and quantitatively adsorbed on silica-PEG. The adsorption decreased at higher volumes. Therefore, for determination of trace quantities of $\mathrm{Fe}^{2+}$ in samples, a sample volume up to $500 \mathrm{~mL}$ could be selected in order to increase the preconcentration factor to 250 . However, in order to decrease the analysis time we used $250 \mathrm{~mL}$ for the preparation of calibration curves for which a preconcentration factor of 125 was employed.

3.7. Analytical Performance. The analytical characteristics of the developed method such as the limit of detection, reproducibility, linear range, and correlation coefficient were obtained by processing standard solutions under optimum conditions. A linear calibration graph was obtained for the determination of iron(II) under the proposed experimental conditions. The data yielded a good linearity in the range of $1-60 \mathrm{ng} \mathrm{mL}^{-1}$ with the equation of $A=0.016 C+0.029(r=$ 0.9989 ) where $A$ is the absorbance and $C$ is the concentration of iron(II) in $\mathrm{ng} \mathrm{mL}^{-1}$. The limit of detection, defined as the concentration of the analyte giving signals equivalent to three times the blank standard deviation, was $0.57 \mathrm{ng} \mathrm{mL}^{-1}$ and relative standard deviations (R.S.D) for ten replicate measurements of 12 and $42 \mathrm{ng} \mathrm{mL}^{-1}$ of iron(II) were 2.4 and $1.7 \%$, respectively.

3.8. Interference Studies. In order to investigate the selectivity of the solid phase extraction procedure, the influence of different ions which could interfere with the determination of iron(II) in various environmental samples was studied. For this purpose constant amounts of iron(II) were taken with different amounts of diverse ions and the general procedure was followed. Any deviation of $\pm 5 \%$ or more from the
TABLE 2: The effect of different ions on the determination of $50 \mathrm{ng} \mathrm{mL}^{-1}$ of iron(II).

\begin{tabular}{lc}
\hline Foreign ions & Tolerance ratio [ion] $] /\left[\mathrm{Fe}^{2+}\right]$ \\
\hline $\mathrm{K}^{+}, \mathrm{NO}_{3}{ }^{-}, \mathrm{SCN}^{-}, \mathrm{NO}_{2}{ }^{-}, \mathrm{Br}^{-}, \mathrm{Mg}^{2+}, \mathrm{Cl}^{-}$ & 1000 \\
$\mathrm{~Pb}^{2+}, \mathrm{I}^{-}, \mathrm{Ca}^{2+}, \mathrm{F}^{-}$ & 500 \\
$\mathrm{Cd}^{2+}, \mathrm{Ba}^{2+}, \mathrm{Cr}^{3+}, \mathrm{Th}(\mathrm{IV})$ & 100 \\
$\mathrm{Ni}^{2+}, \mathrm{Hg}^{2+}$ & 10 \\
$\mathrm{Al}^{3+}, \mathrm{Cu}^{2+}, \mathrm{Co}^{2+}$ & 5 \\
\hline
\end{tabular}

TABle 3: Determination of iron (II) in different samples.

\begin{tabular}{lccc}
\hline Sample & Added $\left(\mathrm{ng} \mathrm{mL}^{-1}\right)$ & Found $^{\mathrm{a}}\left(\mathrm{ng} \mathrm{mL}^{-1}\right)$ & Recovery $(\%)$ \\
\hline \multirow{2}{*}{ Tap water } & - & $\mathrm{ND}$ & - \\
& 4 & $3.9 \pm 0.5$ & 97.5 \\
& 8 & $7.8 \pm 1.0$ & 97.5 \\
Multivitamin $^{\mathrm{b}}$ & - & $7.6 \pm 1.0$ & - \\
& 10 & $17.6 \pm 1.0$ & 100.0 \\
& 20 & $27.5 \pm 1.2$ & 99.5 \\
Spinach $^{\mathrm{c}}$ & - & $39.0 \pm 0.8$ & - \\
& 10 & $48.2 \pm 1.3$ & 97.9 \\
\hline
\end{tabular}

$x \pm t s / \sqrt{n}$ at $95 \%$ confidence $(n=5)$.

${ }^{\mathrm{b}}$ Amount of iron per tablet was $9.7 \mathrm{mg}$.

${ }^{\mathrm{c}}$ Amount of iron was $40.6 \mu \mathrm{g} \mathrm{g}^{-1}$ of spinach.

ND: not detected.

absorbance value of the standard solution was selected as interference. Results given in Table 2 show that the presence of major cations and anions has no significant effect on the determination of iron(II) under selected conditions.

\section{Applications}

The developed method was applied to the determination of iron in tap water, multivitamin tablet, and spinach samples, with satisfactory results (Table 3 ). The concentration of iron(II) could not be determined in water due to its very low concentration. There was a good agreement between the added and the recovered concentrations of the analyte. The obtained mount of iron per tablet was $9.7 \mathrm{mg}$ and the reported value was $10.0 \mathrm{mg}$ which shows that there is good agreement between the two results.

\section{Conclusion}

Silica-PEG is a promising adsorbent which could be used in different ways and this paper presents one of them. The method presented in this paper is highly sensitive and selective for the determination of trace amounts of Fe(II) by spectrophotometry. The detection limits achieved are better than or comparable to some of the previously reported works. A comparison of the proposed method with some of the methods reported in literature is given in Table 4. Moreover, the adsorbent is ecofriendly and stable for at least six month. 
TABLE 4: Comparison of the proposed method with some of the methods reported in literature.

\begin{tabular}{|c|c|c|c|c|}
\hline System & $\mathrm{PF}^{\mathrm{a}}$ & $\begin{array}{c}\mathrm{DL} \\
\left(\mathrm{ng} \mathrm{mL} L^{-1}\right)\end{array}$ & $\begin{array}{l}\text { Breakthrough } \\
\text { volume }(\mathrm{mL})\end{array}$ & Ref. \\
\hline Amberite XAD-2000 & 50 & 0.32 & 250 & {$[1]$} \\
\hline $\begin{array}{l}\text { Modified activated } \\
\text { carbon }\end{array}$ & 10 & 0.38 & 100 & [2] \\
\hline Flotation method & 93 & 0.70 & 750 & [3] \\
\hline BHAPN/SDS-alumina & 63 & 2.60 & 500 & {$[21]$} \\
\hline $\begin{array}{l}\text { Naphthalene loaded with } \\
\text { tetraoctylammonium } \\
\text { bromide }\end{array}$ & 36 & 12.00 & 180 & [16] \\
\hline Silica-PEG & 250 & 0.57 & 500 & $\begin{array}{l}\text { This } \\
\text { work }\end{array}$ \\
\hline
\end{tabular}

Preconcentration factor.

\section{Acknowledgment}

The authors wish to thank Shahid Chamran University, Ahvaz, Iran, for financial support of this project (Grant 1391).

\section{References}

[1] L. Elci, A. A. Kartal, and M. Soylak, "Solid phase extraction method for the determination of iron, lead and chromium by atomic absorption spectrometry using Amberite XAD2000 column in various water samples," Journal of Hazardous Materials, vol. 153, no. 1-2, pp. 454-461, 2008.

[2] M. S. Karacan and N. Aslantaş, "Simultaneous preconcentration and removal of iron, chromium, nickel with $N, N$ etylenebis-(ethane sulfonamide) ligand on activated carbon in aqueous solution and determination by ICP-OES," Journal of Hazardous Materials, vol. 155, no. 3, pp. 551-557, 2008.

[3] H. Karimi, M. Ghaedi, A. Shokrollahi, H. R. Rajabi, M. Soylak, and B. Karami, "Development of a selective and sensitive flotation method for determination of trace amounts of cobalt, nickel, copper and iron in environmental samples," Journal of Hazardous Materials, vol. 151, no. 1, pp. 26-32, 2008.

[4] M. S. Karacan, N. Aslantaş, and H. G. Asian, "Enrichment and removal of iron (II), copper (II) and strontium (II) ions with sulfonamides on activated carbon in environmental samples and determination by ICP-OES analysis," Fresenius Environmental Bulletin, vol. 20, no. 5, pp. 1167-1173, 2011.

[5] M. Soylak and M. Tuzen, "Diaion SP-850 resin as a new solid phase extractor for preconcentration-separation of trace metal ions in environmental samples," Journal of Hazardous Materials, vol. 137, no. 3, pp. 1496-1501, 2006.

[6] V. A. Lemos, R. S. da França, and B. O. Moreira, "Cloud point extraction for $\mathrm{Co}$ and $\mathrm{Ni}$ determination in water samples by flame atomic absorption spectrometry," Separation and Purification Technology, vol. 54, no. 3, pp. 349-354, 2007.

[7] V. Camel, "Solid phase extraction of trace elements," Spectrochimica Acta B, vol. 58, no. 7, pp. 1177-1233, 2003.

[8] Y. Cui, X. Chang, X. Zhu, N. Jiang, Z. Hu, and N. Lian, "Nanometer $\mathrm{SiO} 2$ modified with 5-sulfosalicylic acid as selective solid-phase extractant for Fe(III) determination by ICPAES from biological and natural water samples," Microchemical Journal, vol. 86, no. 1, pp. 23-28, 2007.
[9] N. Pourreza, M. R. Fathi, and Z. Ardan, "Flame atomic absorption spectrometric determination of $\mathrm{Cd}(\mathrm{II}), \mathrm{Ni}(\mathrm{II}), \mathrm{Co}(\mathrm{II})$ and $\mathrm{Cu}(\mathrm{II})$ in tea and water samples after simultaneous preconentration of dithizone loaded on naphthalene," Journal of the Iranian Chemical Society, vol. 7, no. 4, pp. 965-971, 2010.

[10] A. Safavi, N. Iranpoor, N. Saghir, and S. Momeni, "Glycerolsilica gel: a new solid sorbent for preconcentration and determination of traces of cobalt(II) ion," Analytica Chimica Acta, vol. 569, no. 1-2, pp. 139-144, 2006.

[11] N. Pourreza and K. Ghanemi, "Solid phase extraction of cadmium on 2-mercaptobenzothiazole loaded on sulfur powder in the medium of ionic liquid 1-butyl-3-methylimidazolium hexafluorophosphate and cold vapor generation-atomic absorption spectrometric determination," Journal of Hazardous Materials, vol. 178, no. 1-3, pp. 566-571, 2010.

[12] Z. Zang, Z. Li, L. Zhang et al., "Chemically modified attapulgite with asparagine for selective solid-phase extraction and preconcentration of Fe(III) from environmental samples," Analytica Chimica Acta, vol. 663, no. 2, pp. 213-217, 2010.

[13] S. Berijani, M.R. Ganjali, H. Sereshti, and P. Norouzi, "A selective modified nanoporous silica as sorbent for separation and preconcentration of dysprosium in water samples prior to ICPOES determination," International Journal of Environmental Analytical Chemistry, vol. 92, no. 3, pp. 355-365, 2012.

[14] E. Najafi, O. Sadeghi, N. Tavassoli, P. Mirahmadpour, and H. R. L. Z. Zhad, "Flame atomic absorption spectrometric determination of palladium in aqueous samples after preconcentration using nanoparticles of $\gamma$-alumina functionalized with pyridine groups," Analytical Sciences, vol. 26, no. 4, pp. 479-483, 2010.

[15] M. Soylak and Y. E. Unsal, "Chromium and iron determinations in food and herbal plant samples by atomic absorption spectrometry after solid phase extraction on single-walled carbon nanotubes (SWCNTs) disk," Food and Chemical Toxicology, vol. 48 , no. 6, pp. 1511-1515, 2010.

[16] N. Pourreza and H. Z. Mousavi, "Solid phase preconcentration of iron as methylthymol blue complex on naphthalenetetraoctylammonium bromide adsorbent with subsequent flame atomic absorption determination," Talanta, vol. 64, no. 1, pp. 264-267, 2004.

[17] H. Yan, J. Qiao, Y. Pei, T. Long, W. Ding, and K. Xie, "Molecularly imprinted solid-phase extraction coupled to liquid chromatography for determination of Sudan dyes in preserved beancurds," Food Chemistry, vol. 132, no. 1, pp. 649-654, 2012.

[18] N. Pourreza, J. Zolgharnein, A. R. Kiasat, and T. Dastyar, "Silica gel-polyethylene glycol as a new adsorbent for solid phase extraction of cobalt and nickel and determination by flame atomic absorption spectrometry," Talanta, vol. 81, no. 3, pp. 773-777, 2010.

[19] A. R. Kiasat and M. Zayadi, "Polyethylene glycol immobilized on silica gel as a new solid-liquid phase-transfer catalyst for regioselective azidolysis of epoxides in water: an efficient route to 1,2-azido alcohols," Catalysis Communications, vol. 9, no. 10, pp. 2063-2067, 2008.

[20] S. Oszwałdowski and D. Marchut, "Characterization of iron(II) $(\alpha$-diimine $)$ chelates and their interactions with anionic, cationic and non-ionic micelles using the separation, spectrophotometric and computational methods," Analytica Chimica Acta, vol. 540, no. 1, pp. 207-219, 2005. 
[21] M. Ghaedi, H. Tavallali, A. Shokrollahi, M. Zahedi, M. Montazerozohori, and M. Soylak, "Flame atomic absorption spectrometric determination of zinc, nickel, iron and lead in different matrixes after solid phase extraction on sodium dodecyl sulfate (SDS)-coated alumina as their bis (2hydroxyacetophenone)-1, 3-propanediimine chelates," Journal of Hazardous Materials, vol. 166, no. 2-3, pp. 1441-1448, 2009. 

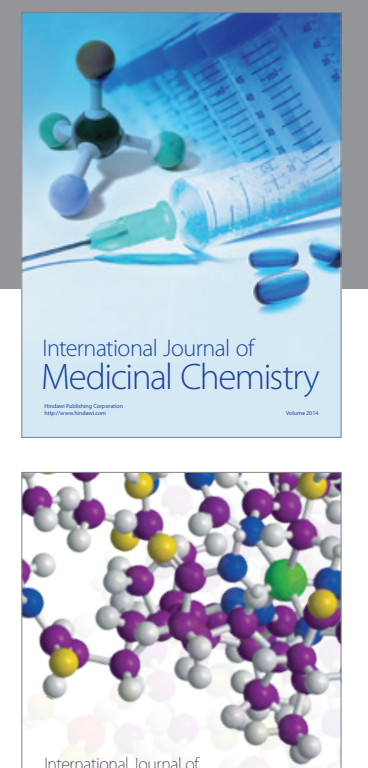

\section{Carbohydrate} Chemistry

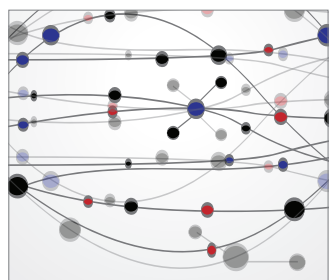

The Scientific World Journal
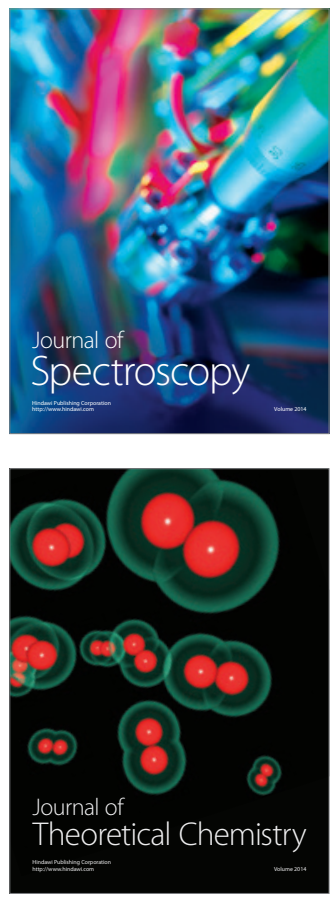
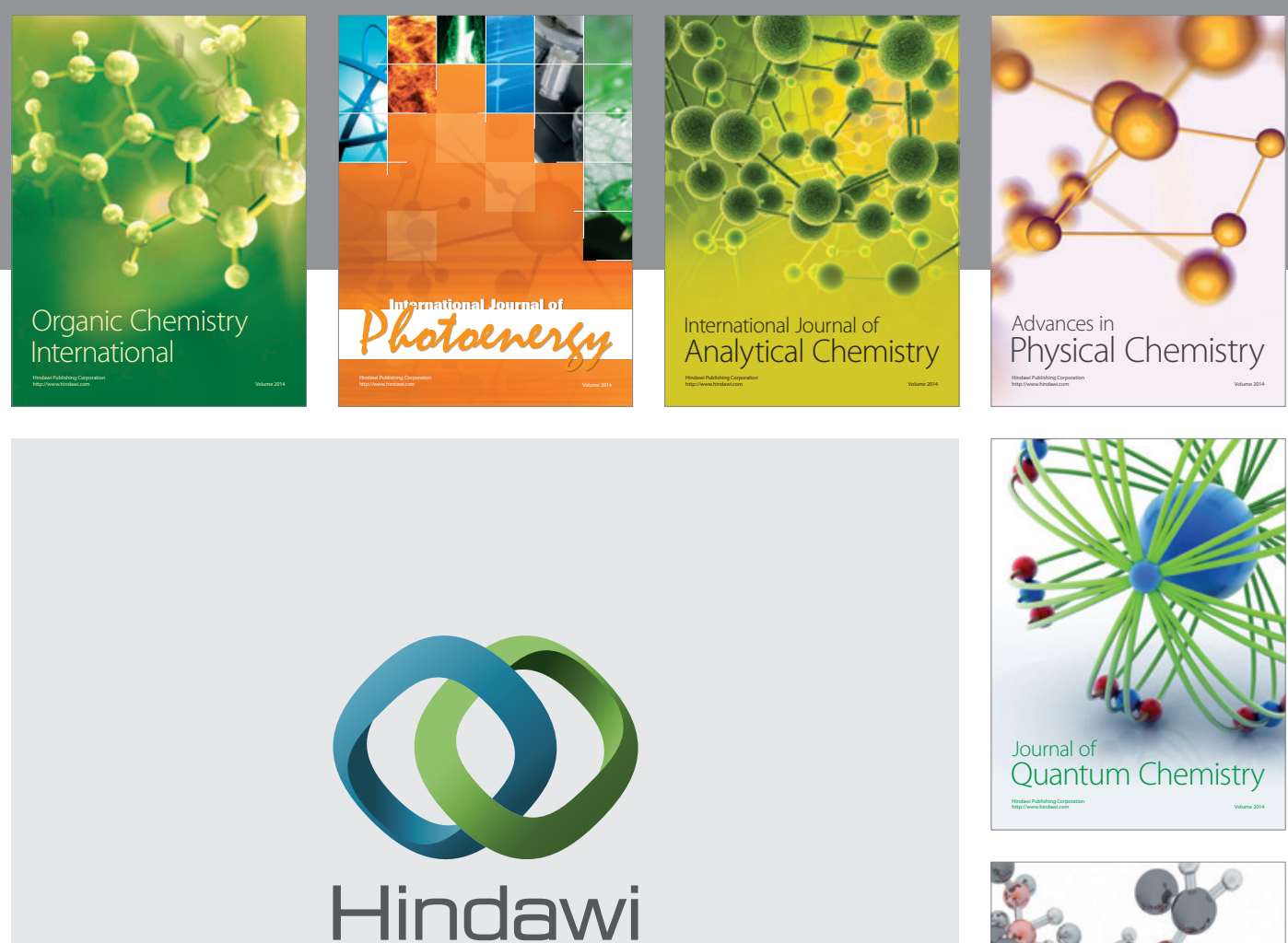

Submit your manuscripts at

http://www.hindawi.com

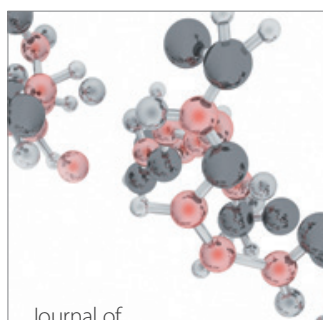

Analytical Methods

in Chemistry

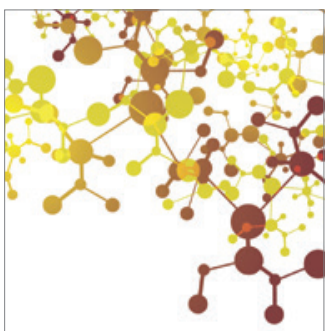

Journal of

Applied Chemistry

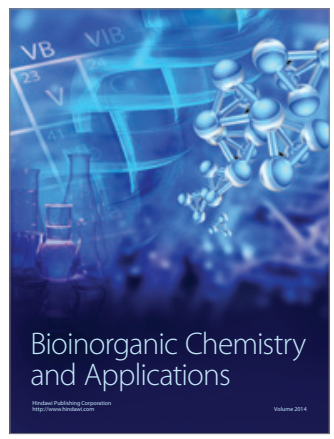

Inorganic Chemistry
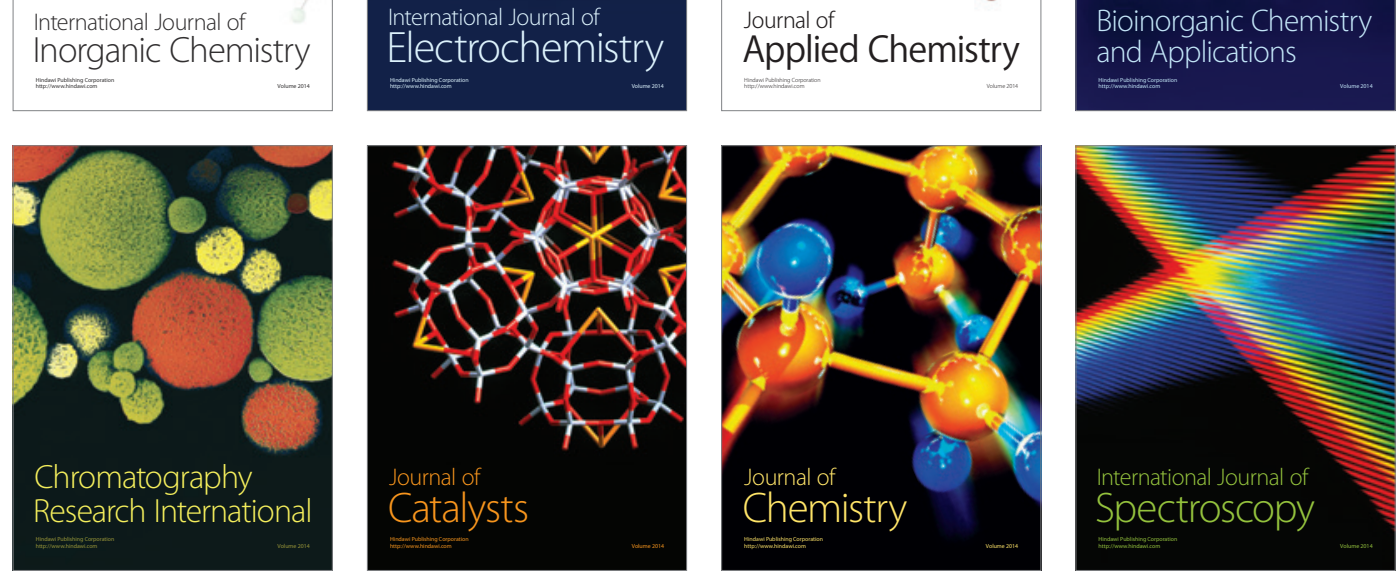